Volume 13

Issue 3 Critical Genocide and Atrocity

Prevention Studies

$11-20-2019$

\title{
Risky Times and Spaces: Settler Colonialism and Multiplying Genocide Prevention through a Virtual Indian Residential School
}

Andrew Woolford

University of Manitoba

Adam Muller

University of Manitoba

Struan Sinclair

University of Manitoba

Follow this and additional works at: https://digitalcommons.usf.edu/gsp

\section{Recommended Citation}

Woolford, Andrew; Muller, Adam; and Sinclair, Struan (2019) "Risky Times and Spaces: Settler Colonialism and Multiplying Genocide Prevention through a Virtual Indian Residential School," Genocide Studies and Prevention: An International Journal: Vol. 13: Iss. 3: 79-96.

DOI:

https://doi.org/10.5038/1911-9933.13.3.1674

Available at: https://digitalcommons.usf.edu/gsp/vol13/iss3/8

This Articles is brought to you for free and open access by the Open Access Journals at Digital Commons @ University of South Florida. It has been accepted for inclusion in Genocide Studies and Prevention: An International Journal by an authorized editor of Digital Commons @ University of South Florida. For more information, please contact digitalcommons@usf.edu. 


\section{Risky Times and Spaces: Settler Colonialism and Multiplying Genocide Prevention through a Virtual Indian Residential School}

\section{Acknowledgements}

The Research presented in this paper was undertaken with approval from the University of Manitoba Psychology/Sociology Research Ethics Board. Funding for our project was provided by a Social Sciences and Humanities Council of Canada Partnership Development Grant. We would like to acknowledge Theodore Fontaine, Caroline Perreault, Mary Courchene, David Rundle Sr., Daniel Highway, Purvis Fontaine, and William Morriseau, whose expertise made this research possible. We also thank Wanda Hounslow, Prairie Skye Young-Brown, Toni Kipling, and Allysa Bird for their research assistance. Further thanks to participants in the Critical Approaches to Genocide and Atrocity Prevention Workshop for their helpful feedback and stimulating discussion. 


\title{
Risky Times and Spaces: Settler Colonialism and Multiplying Genocide Prevention through a Virtual Indian Residential School
}

\author{
Andrew Woolford \\ University of Manitoba \\ Winnipeg, Manitoba, Canada
}

\author{
Adam Muller \\ University of Manitoba \\ Winnipeg, Manitoba, Canada \\ Struan Sinclair \\ University of Manitoba \\ Winnipeg, Manitoba, Canada
}

In the inaugural issue of the official journal of the International Association of Genocide Studies (IAGS), Genocide Studies and Prevention (GSP), then-IAGS president Israel Charny and Chair of the GSP Academic Advisory Board Roger Smith make a spirited argument for inclusion of the word "prevention" in the journal's title:

\begin{abstract}
We recognize that the promise of genocide prevention explicit in our title is very ambitious. How do we prevent genocide from happening? No single step will change the world, but we believe that through careful research and reasoned argument, governments and policy makers can be persuaded to expand their concept of national interest to include the prevention of genocide. We further believe that for governments and policy makers to have the political will to enforce the international laws and conventions on genocide through intervention and prevention, they must be held accountable by their informed constituencies. It is through education and awareness that people are made to understand their responsibility to hold their governments accountable in this regard.
\end{abstract}

While awareness is a first step to the prevention of genocide, cognitive awareness is not enough. In our ever-shrinking world, where there is ever-increasing competition for land and the basic resources for life, the conditions for violent conflict are ever greater. We feel that the key failure of human society has been the failure to adopt life itself as the central value of all human decision making. ${ }^{1}$

In this statement, the authors understand the challenges of prevention to be profound and deeply intersectional. Notwithstanding this complexity, however, they nevertheless decided to place the cause of prevention at the heart of the academic mission of the journal, thereby contributing to structuring our field around this aim.

Genocide Studies and Prevention was birthed in the afterglow of an Enlightenment conception of rational, fully participatory and responsible governance, resting on the presumption that, if world leaders could be convinced by reasoned argument or else feared disapproval from an informed citizenry, the political will to prevent genocide (understood as a man-made and so malleable phenomenon) might become more deeply rooted and blossom. Charny and Smith did not restrict their understanding of prevention to its salience only for members of certain groups, or even solely for those currently under threat of rapidly intensifying and deadly physical destruction. Indeed, their reference elsewhere in their introductory essay to "less visible" but ongoing genocides against Indigenous peoples is testament to the breadth of their conception. ${ }^{2}$ However, through the promise they make, and the way that they make it, certain concessions may be detected that are indebted to a specific logic of prevention, one that hasn't always had welcome consequences for how we understand this term today.

\footnotetext{
${ }^{1}$ Israel W. Charney and Roger W. Smith, “Why GSP?” Genocide Studies and Prevention 1, no. 2 (2006), i. ${ }^{2}$ Ibid.
} 
In this paper, we seek to unsettle the reigning logic of prevention and foster the critical study of genocide prevention by proposing an everyday ethos of genocide prevention, one targeting not just rational thinking but also habituated practices. To foster such a quotidian prevention ethos, we believe it necessary to multiply the points of prevention. We illustrate what we have in mind briefly with reference to our project Embodying Empathy, a virtual Indian Residential School that offers an immersive, empathy-inducing introduction to the cultural destruction wrought through one of the more conspicuous and devastating processes forcing the assimilation of Canada's Indigenous population. Before discussing Embodying Empathy, the next two sections set the stage by articulating the reigning logic of prevention, followed by an examination of how cultural techniques of genocidal destruction have been excluded from this logic. This is followed by critical interrogation of the dominant metaphors used to represent prevention to lay the groundwork for proposing an everyday ethos of prevention that can be inculcated through projects such as Embodying Empathy.

\section{Risk, Culture, and Prevention}

Risk is foundational to the field of genocide studies. Raphael Lemkin's original understanding of genocide as a concept is founded on his realization that historically the law was silent on the risks confronted by human groups as cultural collectivities facing purposive destruction. ${ }^{3}$ More generally, Lemkin argued that the future of humanity was secured and enhanced by our global diversity and pluralism, which he also believed to be at risk from the phenomenon of group destruction. Through the efforts of Lemkin and others, genocide prevention, understood broadly as a determined effort to minimize the risk of genocide, was enshrined in one of our field's founding documents, the United Nations Convention on the Prevention and Punishment of the Crime of Genocide (1948. Hereafter UNGC). ${ }^{4}$

The notion that risks to collectivities can be identified, mitigated, and prevented emerged from an evolving way of thinking that became increasingly prominent and prevalent in the $20^{\text {th }}$ Century. ${ }^{5}$ The turn to risk and prevention thinking is therefore not novel to genocide studies. Genocide studies emerged during the late stages of the "risk society," 6 the period sometimes also referred to as late modernity ${ }^{7}$ in which the tools of science and technology, and the powers of human reason, were seen as keys to a better-managed and less risky modern world. ${ }^{8}$ No longer were disasters merely to be endured when they happened; instead, tools were designed to overcome the pervasive uncertainties of disaster prediction, which in turn led to the creation of new prophylactic measures that could guide intervention when potentially disastrous risks were detected. The practice of genocide assessment and prevention thus was broadly compatible with modernity's essential rationalism. This practice promises to grasp group destruction in such a manner that it is made specifiable (through the production of operational definitions) and actionable (in so far as, once specified, it becomes amenable to epistemic and pragmatic organization in ways that allow for strategic, rationally-grounded interventions).

The contemporary promise of genocide prevention, risk assessment and early warning is built upon a specific way of thinking about genocide that tends to be less inclusive than the approach envisioned by Charny and Smith. For the most part, the logic of genocide prevention builds off the UNGC and therefore inherits its underlying prejudices. This is particularly evident when it comes

\footnotetext{
${ }^{3}$ Raphael Lemkin, Totally Unofficial: The Autobiography of Raphael Lemkin (New Haven: Yale University Press, 2013), $22-24$.

${ }^{4}$ Douglas Irvin-Erickson, Raphaël Lemkin and the Concept of Genocide (Philadelphia: University of Pennsylvania Press, 2017), 152-196; Anton Weiss-Wendt, The Soviet Union and the Gutting of the UN Genocide Convention (Madison: University of Wisconsin Press, 2017), 81-129.

${ }^{5}$ See, in general, Richard Ericson and Aaron Doyle, Uncertain Business: Risk, Insurance and the Limits of Knowledge (Toronto: University of Toronto Press, 2004); Ian Hacking, The Taming of Chance (Cambridge, UK: Cambridge University Press, 1992).

${ }^{6}$ Ulrich Beck, "From Industrial to Risk Society: Questions of Survival, Social Structure, and Ecological Enlightenment," Theory, Culture, and Society 9, no 1 (1992), 97.

${ }^{7}$ Peter Miller and Nikolas Rose, “Governing Economic Life," Economy and Society 19, no. 1 (1990), 1.

${ }^{8}$ See, in general, James Scott, Thinking Like a State: How Certain Schemes to Improve the Human Condition Have Failed (New Haven and London: Yale University Press, 1998).
} 
to the issue of cultural techniques of destruction. Risks to the group as a cultural entity are rarely considered by those operating under the logic of prevention. ${ }^{9}$

Culture is fundamental to the continued existence of groups, since culture is part of what helps them preserve group-sustaining relations. ${ }^{10}$ Culture is thus both the product and constitutive component of group relations. Some definitions of cultural genocide treat culture as a static set of practices and ways of being that need to be preserved as part of the store of the particular group's traditions rather than a collectively negotiated aspect of group life. ${ }^{11}$ In contrast, James Clifford presents culture as a "deeply compromised" notion that has too often been used to place firm boundaries around what is in truth a complex set of relationships. ${ }^{12}$ Culture, for Clifford, is a dynamic grouping of values, practices, and behaviors that are never wholly legible but always in interaction with historical processes of "appropriation, compromise, subversion, masking, invention, and revival." ${ }^{13}$ Culture, in brief, shifts and moves as our relationships unfold. Prevention of cultural genocide therefore involves protecting a set of relations that allow groups to form and re-form as they develop and adapt to changing circumstances. ${ }^{14}$ This raises a vexing question for genocide scholars: How do you protect something that is dynamic and changing? Moreover, because culture is a site of contest and debate, a further question arises: How do you protect something that is itself beset by internal divisions? Yet, at the same time, cultural relations are those through which a group establishes its identity, produces meaning for its members, and ensures its preservation into the future. Violence against these relations can therefore compromise the continued existence of a group in a manner similar to physical and biological violence, as captured in Claudia Card's notion of "social death," which articulates the deep ontological distress caused through destruction of relations that are fundamental to our social vitality..$^{15}$ Such violence against culture is purposeful and seeks to expunge society of the targeted culture and is therefore different from other processes of inter-group cultural sharing and hybridity.

The tendency of the logic of prevention to ignore cultural destruction stems from the formative process giving rise to the genocide concept in international law. Of particular, concern is the excision of the concept of cultural genocide from the UNGC. ${ }^{16}$ When discussing the question of cultural genocide, some delegates to the UN's General Assembly found ridiculous the idea that their nations might have been complicit in the destruction of cultural groups through acts they felt to be part of normal procedures intended to yield civilization and moral uplift. Evolutionary standards for assessing the value of groups were still present at this time, and Lemkin was hesitant

${ }^{9}$ See, for example, Chad Hazlett, New Lessons Learned? Improving Genocide and Politicide Forecasting (Washington, DC: United States Holocaust Memorial Museum, 2011), accessed January 7, 2019, https://www.ushmm.org/m/ pdfs/20111102-hazlett-early- warning-lessons-learned.pdf; Anna Matveeva, Early Warning and Early Response: Conceptual and Empirical Dilemmas (Netherlands: European Centre for Conflict Prevention, 2006); Nate Kaken et al., Fragile States Index 2014 (Washington, DC: The Fund for Peace, 2014); Birger Held, "Risks, Early Warning and Management of Atrocities and Genocide: Lessons from Statistical Research," Politorbis 47, no. 2 (2009), 65-70.

${ }^{10}$ For a robust overview of the origins and historical development of the culture concept, including a discussion of the main contemporary schools of thought on what culture is and how it works, see the introduction to Adam Muller's collection Concepts of Culture: Art, Politics, and Society (Calgary: University of Calgary Press, 2005).

${ }^{11}$ For example, Beardsley defines ethnocide as the "[...] intent to extinguish, utterly or in substantial part, a culture. Among such ethnocidal acts are the deprivations of opportunity to use a language, practice a religion, create art in customary ways, maintain basic social institutions, preserve memories and traditions, and work in cooperation toward social goals." Quoted in Leo Kuper, Genocide: Its Political Use in the Twentieth Century (New Haven: Yale University Press, 1981), 31. See also Paul Clastres, “On Ethnocide," Art \& Text 28 (1988), 51-58.

${ }^{12}$ James Clifford, The Predicament of Culture: Twentieth-Century Ethnography, Literature, and Art (Cambridge: Harvard University Press, 1988).

${ }^{13}$ Ibid., 338.

${ }^{14}$ On the movement between of tradition and change within oral cultures, see also Albert B. Lord, The Singer of Tales (New York: Atheneum, [1960] 1965); Jan Vansina, Oral Tradition as History (Madison: University of Wisconsin Press, 1985).

${ }^{15}$ Claudia Card, Confronting Evils: Terrorism, Torture, Genocide (Cambridge: Cambridge University Press, 2010).

${ }^{16}$ For an overview, see Jeff Benvenuto, "From Cultural Genocide to Cultural Integrity: Indigenous Rights and the Cooptation of International Norms" (PhD diss., Rutgers University, 2018); Irvin-Ericson, Raphaël Lemkin and the Concept of Genocide; Johannes Morsink, "Cultural Genocide, the Universal Declaration, and Minority Rights," Human Rights Quarterly 21, no. 4 (1999), 1009-1060. See also, Hirad Abtahi and Philippa Webb, The Genocide Convention: The Travaux Préparatoires, 1st ed. (Leiden and Boston: Martinus Nijhoff, 2008). 
to suggest that sovereign nations did not have some right to try to integrate subject peoples. In this vein, Mr. Petran, the representative from Sweden, noted that

\begin{abstract}
The acts which, according to article III [on cultural genocide], would constitute cultural genocide might be far less serious than those specified in article II; for instance, in the case of measures of educational policy, it might be difficult to estimate their scope in relation to the cultural position of a minority. The question could arise whether, for example, the fact that Sweden had converted the Lapps to Christianity might not lay her open to the accusation that she had committed an act of cultural genocide. ${ }^{17}$
\end{abstract}

The thought that colonial powers could be impugned for their efforts to transform allegedly "backward" Indigenous peoples struck the delegates as outrageous, so barely worth consideration that they did not hesitate to bring up their "civilizational" efforts in condemning the article on cultural genocide. Mr. Leif Egeland from South Africa likewise raised the specter of cannibalism, noting there is "danger latent in the provisions of article III where primitive or backward groups were concerned. No one could, for example, approve the inclusion in the convention of provisions for the protection of such customs as cannibalism."18

Other representatives argued that: a) physical and cultural genocide were too different to combine under the same law; b) cultural genocide was covered by other legal protections (such as those concerning minority rights to be included in the UN Declaration of Human Rights that was being negotiated at the same time); and c) the article on cultural genocide was too vague to be of any legal practicality. Danish representative Per Federspiel raised two of these objections in his remarks: "it would show a lack of logic and of a sense of proportion to include in the same convention both mass murders in gas chambers and the closing of libraries." ${ }^{19}$ Some nations such as Egypt and China opposed these arguments, pointing to the destructiveness of forced conversions and other assaults on the cultural life of the group, but to no avail: in the Sixth Committee, 25 nations voted in favor of excluding cultural genocide from the UNGC versus 16 against and 4 abstentions. ${ }^{20}$

The memory of the Holocaust as an event of mass physical destruction, rather than primarily cultural and physical destruction, contributed to the removal of techniques of cultural genocide from the UNGC. In their efforts to reduce the law of genocide to whatever could be deemed justiciable, the Holocaust was mobilized as a frame of reference and used to narrow the concept to emphasize very nearly only its physical manifestation. As can be seen in Federspiel's comments, to compare mass murders with closed libraries was to dilute and distort the genocide concept beyond reason. As Alexander Hinton notes, the argument of "dilution" has continued to perform a gate-keeping function, limiting what reasonable accusations might be made concerning acts of attempted group destruction..$^{21}$ However, these arguments against dilution often served simply to cover over the self-interest of the participating nations, who wanted to protect themselves from genocide accusation as processes of decolonization were taking place around the globe.

In short, practices of cultural genocide were removed from the UNGC for a variety of reasons, from the pragmatic to the nakedly prejudicial. On the latter score, one cannot deny that some delegates to the General Assembly believed quite simply that some cultures were worthier of protection than others. They raised concerns about the protection of "backward" languages and

\footnotetext{
${ }^{17}$ Abtahi and Webb, The Genocide Convention, 1506.

${ }^{18} \mathrm{Ibid} ., 1513$. Article III on cultural genocide was eventually excised from the UNGC, although it was still present as late as the Ad Hoc Committee on Genocide's 1948 draft. In this version, Article III reads: "In this Convention genocide also means any deliberate act committed with the intent to destroy the language, religion or culture of a national, racial or religious group on grounds of national or racial origin or religious belief such as: 1 . Prohibiting the use of the language of the group in daily intercourse or in schools, or the printing and circulation of publications in the language of the group; 2. Destroying, or preventing the use of, libraries, museums, schools, historical monuments, places of worship or other cultural institutions and objects of groups," as quoted in Morsink, Cultural Genocide, 1023.

${ }^{19}$ Ibid., 1508.

${ }^{20}$ Ibid., 1518.

${ }^{21}$ Alexander Laban Hinton, "Critical Genocide Studies," Genocide Studies and Prevention 7, no. 1 (2012), 10.
} 
religions. Overconfidence in Western superiority and attendant Eurocentric biases thus worked their way into the conceptual architecture of the UNGC.

Accordingly, the logic of prevention can also be seen to operate as a "logic of elimination." Just as the logic of elimination, as identified by Patrick Wolfe, works to erase Indigenous presence upon the land while naturalizing non-Indigenous settlement, the logic of prevention turns our gaze away from the many means of elimination (e.g., forced assimilation, removal, linguistic and political destruction), thereby allowing us to imagine North America as a space not needing prevention..$^{22}$ Indigenous groups, and the centrality of culture to the ongoingness of these groups, are defined out of the scope of genocide and so out of the scope of prevention, facilitating the perpetuation of a settler colonial logic of elimination by legal and other means.

\section{The Logic of Prevention}

The colonial logic of prevention manifests in the way that culture is discussed and treated in the mainstream literature on genocide prevention, risk assessment and early warning. Therein, for the most part, culture receives little mention. Some reports discuss the creation of a "culture of prevention" or a "culture of peace," and warnings are sometimes given about regions where there is a culture of obedience or authoritarianism, thus making certain kinds of culture serve as potential warning signs or precursors to genocide, but little is said of the actual cultures threatened by genocide. ${ }^{23} \mathrm{~A}$ review of some illustrative examples is thus in order.

The report of the Genocide Prevention Task Force, Preventing Genocide: A Blueprint for U.S. Policy Makers, co-chaired by Madeleine K. Albright and William S. Cohen (2008), is an example of the blind spots inherited from the UNGC that are sustained in the logic of prevention. In this report, culture is problematized in the form of the reigning institutional culture in the United States, which is seen as being one that favours reactive rather than preventative practices. ${ }^{24}$ This is a key focus of the report, since the task force was established with the purpose to "identify practical steps to enhance the capacity of the U.S. government to prevent and respond to genocide and mass atrocities." ${ }^{25}$ Of course, in giving such advice, the report also needs to touch on how to identify when prevention is warranted. Here, the report seeks to sidestep messy entanglements inherent in the question "What is genocide?" by focusing instead on "genocide and mass atrocities" that target victims "because of their membership as members of a group." ${ }^{26}$ Despite this self-professed open approach, it is clear that the report is only concerned with instances of physical destruction. Cultural destruction may be something implicitly noted in references to the sort of "fine-grained" analysis the authors feel is necessary to effective and efficient early warning and risk assessment, though it does not receive specific attention per se..$^{27}$

It is further clear in the report that culture may play a role in the lead-up to genocide. For example, a culture of impunity that follows prior mass atrocities is noted as a possible precursor to an occurrence of genocide. ${ }^{28}$ Likewise, the risk factor of "state-led discrimination" can be read

\footnotetext{
${ }^{22}$ Patrick Wolfe, "Settler Colonialism and the Elimination of the Native," Journal of Genocide Research 8, no. 4 (2006), 387409.

${ }^{23}$ See for example, John N. Clarke, "Early Warning Analysis for Humanitarian Preparedness and Conflict Prevention," Civil Wars 7, no. 1, (2005), 71-97; United Nations Office of the Special Adviser for the Prevention of Genocide and the Responsibility to Protect, Framework of Analysis for Atrocity Crimes: A Tool for Prevention, (New York: United Nations, 2014); Gregory H. Stanton, "How we can Prevent Genocide: Building an International Campaign to End Genocide," Genocide Watch, 2013, accessed January 14, 2019, http://www.genocidewatch.org/howpreventgenocideic.html; Christoph O. Meyer et al., "Recasting the Warning-Response Problem: Persuasion and Preventive Policy," International Studies Review 12, no. 4 (2010), 556-578.

${ }^{24}$ Madeline K. Albright and William S. Cohen, Preventing Genocide: A Blueprint for U.S. Policymakers (Washington, DC: United States Holocaust Memorial Museum, 2008), accessed January 14, 2019, https://www.ushmm.org/m/ pdfs/20081124-genocide-prevention-report.pdf, 1, 26, 29, 62.

${ }^{25}$ Ibid., $x$.

${ }^{26}$ Ibid., xxii.

${ }^{27}$ Ibid., 18.

${ }^{28}$ Ibid., 46.
} 
as potentially including assaults on group culture, although again this is not explicitly stated. ${ }^{29}$ In large part, the report's preventative lens does not focus on assaults against the cultural life of targeted groups, and so fails to do enough to acknowledge cultural destruction as in itself a technique of genocide.

Since reports such as that of the Genocide Prevention Task Force piggyback on the existing early warning, risk assessment and prevention literature, it is necessary to look and see how it, too, operates using a similar logic of prevention that overlooks the genocidal force of cultural destruction. In this scholarly literature, one sees a narrowing lens that relegates assaults against culture largely to the sidelines. ${ }^{30}$ The logic of prevention thereby remains ironically consistent with the logic of elimination, despite the former's commitment to forestalling genocide.

Though anthropologists such Hinton have brought to genocide studies an enhanced understanding of the cultural conditions characteristic of particular regions (Cambodia) and their relationship to genocidal processes, scholars approaching genocide prevention from a social scientific perspective frequently exhibit little regard for the role of culture in both the perpetration and resolution of genocide. ${ }^{31}$ Barbara Harff, whose pioneering work on genocide prevention has set the stage for subsequent authors working on quantitative aspects of the field, re-works the UNGC when she seeks to operationalize a concept of genocide and politicide for her research. ${ }^{32}$ In so doing, she criticizes the UNGC for including "mental harm" as a form of genocide in Article II(b), arguing that "it encompasses a vast array of instances of psychological and cultural harm done to groups that have lost their cohesion and identity, but not their lives." ${ }^{33}$ She offers no comment on Article II(e) on the transfer of children from one group to another. Cultural destruction is simply defined out of her equations.

If cultural destruction is not an outcome that such scholars consider to merit prevention, does it at least appear in their work as a potential warning sign? Not so much. The analytical emphasis in this kind of scholarship focuses on macro-level factors such as state policy, histories of previous conflict, racial and ethnic cleavages, and underlying economic conditions. Harff does note factors such as "exclusionary ideologies," ${ }^{34}$ but these are registered more because of their capacity to prime perpetrators toward physical genocidal action, rather than as assaults against the integrity and continuity of targeted groups.

More examples could be provided, but the point is straightforward: constructed within a legal regime that stacks the deck against general recognition of the genocidal significance of colonial assaults on Indigenous cultures, the logic of prevention offers no solace and provides no potential means of salvation to those facing cultural forms of group destruction. The same logic that resulted in the removal of cultural genocide from the UNGC is operative in the decision-making featured in both policy-oriented and scholarly interventions on questions of prevention. Within these domains, cultural destruction is often seen as too messy, qualitatively different, or of too little importance to require mention. These rationales draw upon liberal European ontological and epistemological

\footnotetext{
${ }^{29}$ Ibid., 25.

${ }^{30}$ See for example, Nicolas Rost, "Will it Happen Again? On the Possibility of Forecasting the Risk of Genocide," Journal of Genocide Research, 15, no. 1 (2013), 41-67; Benjamin E. Goldsmith et al., "Forecasting the Onset of Genocide and Politicide: Annual Out-of-Sample Forecasts on a Global Dataset, 1988-2003," Journal of Peace Research 50, no. 4 (2013), 437-452; Benjamin E. Goldsmith and Charles R. Butcher, "Genocide Forecasting: Past Accuracy and New Forecasts to 2020," Journal of Genocide Research, 20 no. 1 (2018), 90-107; David A. Hamburg, Preventing Genocide: Practical Steps Toward Early Detection and Effective Action (New York: Routledge, 2015); Barbara Harff, "Detection: The History and Politics of Early Warning," in Responding to Genocide: The Politics of International Action, eds. Adam Lupel and Ernesto Verdeja (Boulder: Lynne Rienner Lynne Rienner Publishers, Inc., 2013), 57-73; Heldt, Risks, Early Warning and Management; Scott Straus, Fundamentals of Genocide and Mass Atrocity Prevention (Washington, DC: United States Holocaust Memorial Museum, 2011), accessed January 14, 2019, https://www.ushmm.org/m/pdfs/Fundamentals-ofGenocide-and-Mass-Atrocity-Prevention.pdf.

${ }^{31}$ For example, Alexander Laban Hinton, Why Did they Kill? Cambodia in the Shadow of Genocide (Berkeley: University of California Press, 2005).

${ }^{32}$ Barbara Harff, "No Lessons Learned from the Holocaust? Assessing Risks of Genocide and Political Mass Murder since 1955," American Political Science Review 97, no. 1 (2003), 57-73.

${ }^{33}$ Ibid., 58.

${ }^{34}$ Ibid., 62.
} 
assumptions that place individuals and their physical existence at the centre of group life. And they downplay or otherwise ignore the cultural relations that constitute groups and contribute to their ongoingness..$^{35}$ Moreover, it is their fit with the law, and how they come to be known through European legal practices that determines the relevance of the criteria whereby we are meant to become able to determine when and where there is a potential genocide to be prevented. How groups experience and understand their own potential destruction, especially where it resides outside a European knowledge/experiential framework, simply matters less. ${ }^{36}$

\section{Binaries, Clusters, Events, Circle, Line, Intensities}

Beyond the neglect of culture in scholarly and policy literature on genocide prevention, we contend there is a structural problem in the logic of prevention that locks it in patterns of modernist and categorical thinking insensitive to the everyday intimacies of genocide. In brief, the logic of prevention is represented through a variety of (often mathematical) metaphors that presuppose a neat and rational world. Because our ultimate concern in this paper is with representation, we will focus in what follows on how these metaphors of risk and prevention are typically visualized in genocide studies.

Most prevalent among the early metaphors are those of the binary and the line. Genocidal processes emerge either in one nation state or another-there is little regard for the indeterminate zones that exist between the nations of the world. Instances of genocide might happen to cluster in specific regions, but these spaces are distinctly segregated and carved so as to reflect a specific geospatial conceptualization of the world, one that reinforces the idea of sovereign space. It is therefore the nation that remains the primary unit for the logic of prevention, no matter how contested that Westphalian framework might happen to be by those who live under its imposed (and in some important sense arbitrary) order.

Within this national space, a particular trait or risk factor is usually understood to be either present or absent. For example, it might be asked: Has the country experienced a previous instance of genocide or mass violence? Yes or no. Is there evidence of an exclusionary ideology? Yes or no. Responses may be coded into multi-modal rather than bi-modal responses, but the basic parameters remain ones of a presence or an absence, the binarized logic of a finite machine state (either on or off, present or absent).

The metaphor of the circle is also sometimes introduced with a view to capturing the notion that previous violence increases the risk of future violence. This metaphor contributes to perceptions of the cyclical nature of mass violence, in other words the idea that violent history repeats itself unless intervention occurs. Such circles are often drawn between temporally and geographically isolated events, in a back-handed way contributing to the idea of genocide as a distinct point in time marked by definite boundaries. Accordingly, the circle of genocide may be seen to be nothing more than another kind of line connecting events, with risks of heating up or cooling off viewed as depending upon a number of identifiable (and shared) factors.

Such linearity is most obvious in stage models for predicting and preventing genocide. ${ }^{37}$ Under their logic, (pre)genocide begins slowly and increases in intensity until it blooms into fullfledged genocide. This development may be rendered metaphorically as either a straight line or a tree branching off in different (binary) directions, the exact structure of which will depend on a variety of yes/no or if/then-type decisions. If one can define/track/observe a potential direction to a sequence of events, then the logic of prevention holds that we can try to staunch the flow of genocidal actions.

\footnotetext{
${ }^{35}$ Dirk A. Moses, "Conceptual Blockages and Definitional Dilemmas in the 'Racial Century': Genocides of Indigenous Peoples and the Holocaust," Patterns of Prejudice 36, no. 4 (2002), 7-36.

${ }^{36}$ Andrew Woolford, "Ontological Destruction: Genocide and Aboriginal Peoples in Canada," Genocide Studies and Prevention 4, no. 1 (2009), 81-97; Andrew Woolford, "Decriminalizing Settler Colonialism: Entryways to Genocide Accusation and Canadian Absolution," in Entryways and Criminalization, eds. George Pavlich and Matthew Unger (Edmonton: University of Alberta Press, 2019).

${ }^{37}$ Gregory Stanton, “The Ten Stages of Genocide," Genocide Watch, 2016, accessed December 5, 2018, http://www. genocidewatch.net/wp-content/uploads/2012/06/The-Ten-Stages-of-Genocide-handout.pdf.
} 
What these kinds of linear and teleological models gain in parsimony and practicality, however, they often lose in explanatory and predictive subtlety. Some practitioners of genocide risk assessment and prediction rightly acknowledge that their models only provide access to certain types of genocide, and in particular are less successful in identifying and making sense of the pulsating and mutating relations and processes responsible for slow genocides ${ }^{38}$ characteristic $^{2}$ of settler-colonial genocide. ${ }^{39}$ Consequently if we are serious about addressing the varieties of genocidal processes and threats, it is necessary to open up the logic of prevention to new metaphors, to the promise of prevention at a molecular rather than a molar level, and so multiply what we propose referring to as the everyday ethos of prevention. ${ }^{40}$

\section{The Open World, The Story World: Genocide's Molecular Flows}

It is not our contention that certain forms of genocidal destruction are undetectable and actionable at a broader, molar level. Indeed we accept that some kinds of genocide can be recognized on a broad surface with the aid of metaphors of lines, binaries, circles, events, and intensities. Molar calculations of prevention, as calculations based on the analysis of generalized phenomena, are sometimes successful in approximating and distilling genocidal probabilities. They assist us in envisioning the surfaces of genocidal phenomena, especially when such surfaces are unmistakably drenched in blood. In such circumstances, the linear, tree-model, might effectively allow us to emplot the course of a genocide from root to branch, opening spaces for preventative actions (although in assessments of efficacy it is sometimes worth remembering that one can never be sure that an act that did not happen was in fact prevented). So, then we accept that models drawing on a conventional stock of otherwise limited and limiting metaphors can sometimes create narrative structures about genocidal progressions that open up possibilities for more and less preventatively successful actions on the ground and political interventions in accordance with the reigning (formal and informal) rules of the prevailing geopolitical order.

But even in cases of seemingly clear-cut, readily observable genocides it is also worth remembering that operations take place at a molecular or microphysical level, and acknowledging that complexities are often lost, distorted, or ignored through the distillation processes required for emplotment. To provide one example, conventional prevention models do not deal with genocidal intimacies, the everyday and molecular flows of and between relationships that make attempted group destruction possible. ${ }^{41}$ Genocide occurs both to and through relationships. These relationships are not ordinarily captured by macro-level data and the work that is done to smooth the edges and constitute the conceptual boundaries of the violent phenomena under study. However, it is precisely in our everyday relations with one another that group destruction is made thinkable, habituated, innovated, and, in general, practiced..$^{42}$ Identifying and intervening in

\footnotetext{
${ }^{38}$ Kjell Anderson, “Colonialism and Cold Genocide: The Case of West Papua," Genocide Studies and Prevention 9, no. 2 (2015), 9-25.

${ }^{39}$ Hollie N. Brehm, “Re-examining Risk Factors of Genocide," Journal of Genocide Research 19, no. 1 (2017), 61-87.

${ }^{40}$ Our use of the terms "molar" and "molecular" is indebted to the work of Gilles Delueze and Félix Guattari, particularly their landmark study A Thousand Plateaus: Capitalism and Schizophrenia (London: Bloomsbury Publishing, 1988). Writing in The Deleuze Dictionary (Edinburgh: Edinburgh University Press, 2005), Tom Conley explains that in $A$ Thousand Plateaus: “Deleuze and Guattari apply the 'molar' and 'molecular' to political bodies. Molar entities belong to the State or the civic world. They are well defined, often massive, and are affiliated with a governing apparatus. Their molecular counterparts are micro-entities, politics that transpire in areas where they are rarely perceived: in the perception of affectivity, where beings share ineffable sensations; in the twists and turns of conversation having nothing to do with the state of the world at large; in the manner, too, that a pedestrian in a city park sees how the leaves of a linden tree might flicker in the afternoon light." Tom Conley. "The Deleuze Dictionary: Molar," Academic Dictionaries and Encyclopaedias, accessed December 5, 2018, http://deleuze.enacademic.com/110/molar.

${ }^{41}$ See, in general, Laura Ann Stoler, Carnal Knowledge and Imperial Power: Race and the Intimate in Colonial Rule (Berkeley and Los Angeles: University of California Press, 2002); Cathleen D. Cahill, Federal Mothers and Fathers: A Social History of the United States Indian Service, 1869-1933 (Chapel Hill: University of North Carolina Press, 2011); Margaret D. Jacobs, White Mother to a Dark Race: Settler Colonialism, Maternalism, and the Removal of Indigenous Children in the American West and Australia, 1880-1940 (Lincoln: University of Nebraska Press, 2009).

${ }^{42}$ For practice-based analysis of genocide, see Margaret D. Jacobs, "The Habit of Elimination: Indigenous Child Removal in Settler Colonial Nations in the Twentieth Century," in Colonial Genocide in Indigenous North America, eds. Andrew
} 
destructive relations requires more than identifying the general circulation of a genocidal ideology or exclusionary policies and practices - it requires thick description of the everyday forms of social engagement and friction that make a genocide possible.

If one accepts the existence and power of genocide's quotidian and affective dimensions, then it is not a great leap to argue that it is within everyday structures, feelings, and interactions that we also can locate a space of prevention. We feel this is particularly evident in cases of ongoing settler colonial relations of destruction that persist in threatening Indigenous ways of being and becoming. One such egregious case, that of Canadian Indian Residential Schools (IRS), serves as a particularly vivid example of how genocidal intimacies were deployed for the purposes of group destruction, predominantly through cultural means. Between the 1880s, until the last school closed in 1996, Canada's IRS served to remove upward of 150,000 Indigenous children from their families and communities, in the process deliberately replacing the intimacy characteristic of the Indigenous world with the twin terror-intimacies of physical and sexual abuse, supplemented by the promised future intimacy (never to be fully realized) derived from assimilation. ${ }^{43}$ Through the push of punishment and the pull of inclusion, Indigenous cultures were forcibly relegated to a bygone and backward past, a displacement making it possible for the settler colonial Canadian state to claim sovereignty over and within Indigenous nations. ${ }^{44}$

The complex topography - distributed across multiple times, spaces and cultures - of the IRS example does not easily map onto the measures of risk and prevention identified in the mainstream genocide prevention literature. However, it does have the potential to be signaled and unsettled through forms of the educational work that Charny and Smith correctly identify in "Why GSP?" as a component of prevention. ${ }^{45}$ Their mistake, however, involves limiting their conception of "education" to a notion of cognitive awareness of the sort that is always susceptible to the distancing and indifference-making patterns of the modern world, alongside a moral education that prioritizes the value of life. In their (liberal-educational) model, cognitive and moral awareness holds the promise of straightforwardly resulting in transformative action through the creation of reasonable and ethical citizens who demand that their political representatives intervene to halt or otherwise address genocidal circumstances. The process is, they assume, largely rational, and it operates through appropriately molar political channels to bring about the cessation of violence and an end to human suffering. Unfortunately, Charny and Smith do not critique these channels and their normative outcomes and tactics (e.g., sanctions and military intervention). Most problematically from our perspective, this model remains at the molar level and does not efficiently either take into account or recommend strategies suitable for preventing molecular genocidal violence.

We argue that one important way to educate and work both to prevent and redress genocide molecularly is through artistic renderings of genocidal experiences. Through artworks it becomes possible not only to deploy cognitive-educational tools conducive to an ethos of prevention in the individual, but also to cultivate empathetic and unsettling responses in secondary witnesses. This is not of course to suggest that artworks are the only or even the main expressive vehicle through which empathy can be cultivated; indeed works of history and biography, both creative and expressive enterprises in their way, can also yield similar results. But the latter genres tend to engage empathy when they are the most "expressive," by which we mean they work to illuminate or interpellate states of mind and feelings that reveal the more intimate and contingent aspects

Woolford, et al (Durham: Duke University Press, 2014); Christopher Powell, Barbaric Civilization: A Critical Sociology of Genocide (Montreal and Kingston: McGill-Queen's University Press, 2011).

${ }^{43}$ For an overview of residential schools in Canada, see James Rodger Miller, Shingwauk's Vision: A History of Native Residential Schools (Toronto: University of Toronto Press, 1996); John S. Milloy, A National Crime: The Canadian Government and the Residential School System, 1879 to 1986 (Winnipeg: University of Manitoba Press, 1999); Truth and Reconciliation Commission of Canada, Honouring the Truth, Reconciling for the Future. Summary of the Final Report of the Truth and Reconciliation of Canada (Ottawa: Government of Canada, 2015); David B. MacDonald and Graham Hudson, "The Genocide Question and Indian Residential Schools in Canada." Canadian Journal of Political Science 45, no. 2 (2012), 434; Andrew Woolford, This Benevolent Experiment: Indigenous Boarding Schools, Genocide and Redress in North America (Lincoln and Winnipeg: University of Nebraska and the University of Manitoba Press, 2015).

${ }^{44}$ Woolford, This Benevolent Experiment.

${ }^{45}$ Charny and Smith, Why GSP?, i. 
of lived experiences - e.g. the highly subjective and potentially "relatable" ways that people make sense of what is happening to them, particularly in so far as we are concerned at times of constraint and distress. Following scholar and therapist Mitchell Kossak, ${ }^{46}$ we believe that creative artworks facilitate "attunement" with the world, both by modelling what attunement looks like and by demonstrating the consequences and costs of "misattunement." In becoming attuned to the world - by learning to understand and accept the world's inhabitants, folkways, and risks empathy plays a central role by creating opportunities for learning from the world as others see and understand it. Creative or expressive representations, by drawing our attention (in, say, works of fiction) to variations in the way we negotiate our lived realities, and by revealing how these variations have come to mean something to the artists producing the representations of them, invite us to think differently and, often, to care. When we do, when we respond positively to the invitation to enter others' lives that artworks extend to us, we facilitate, without in any way overdetermining, the emergence of empathetic connections and the expectation that we need to care. Notwithstanding the work of scholars like Paul Bloom and others who are overtly suspicious of any claim that empathy might possibly contribute to the refinement of our moral sensibility and ethical comportment, ${ }^{47}$ we remain convinced that empathy has a role to play in allowing us to enter into the lives of others in ways that, under certain circumstances, contribute to narrowing the distance between "Us" and "Them," and through this narrowing aid in fostering a way of being in the world more finely attuned to the harms inherent in genocidal intimacies and hospitable to the demands of genocide prevention and repair. The argument over the moral and practical utility of empathy is a large one that generally exceeds the scope of this writing. It is acknowledged here only by way of admitting that there remains some controversy over about what tools are best suited to the work of genocide prevention at the molecular level (empathy, Bloom's "rational compassion," etc.).

For our part, we are exploring possible answers to this question through the production and implementation of a uniquely twenty-first-century prototype of genocide education and prevention practice that we are calling a "virtual storyworld." In this wholly digital domain, interactions are less scripted and open to multi-focal and multi-dimensional experiences. Though the story at the heart of the digital world has been designed to elicit affective and empathetic responses through the production of evocative sounds, moods, colors, and perspectives, it also makes possible unique interactions and experiences that can be incorporated into the individual's personal storehouse of moral and other dispositions. ${ }^{48}$ The storyworld thus holds the promise of being able to familiarize an individual, through seemingly everyday (and so molecular) interactions, with both the ethic and practice of caring. In this way the storyworld promises to give those experiencing it access to an everyday experience of genocide prevention through the recalibration of human relations.

\section{Embodying Empathy}

The Embodying Empathy project is led by a group of residential school Survivors with whom we researchers have been working for several years now to design, build and test a virtual Indian Residential School (vIRS). Using an Oculus Rift headset and other leading-edge technologies, our project has constructed a dynamically interactive and immersive IRS storyworld, a virtual realitybased environment that provides carefully-rendered IRS interior and exterior spaces, photographs and Survivor narratives for users to experience, interact with, and transform in various ordinary (and sometimes troublingly intimate) settings. Survivor-led representations of their experiences are thereby made available to a great variety of end users, including other Survivors, intergenerational Survivors, non-Indigenous Canadians, recent immigrants and others. Through the spaces, images and testimony contained within the storyworld, as well as through its introductory and closing

\footnotetext{
${ }^{46}$ Mitchell Kossak, Attunement in Expressive Art Therapy: Toward an Understanding of Embodied Empathy (Springfield: Charles C. Thomas, 2015).

${ }^{47}$ Paul Bloom, Against Empathy: The Case for Rational Compassion (New York: HarperCollins/Ecco, 2016).

${ }^{48}$ Pierre Bourdieu's work on the habitus is useful in this regard, see Pierre Bourdieu, In Other Words: Essays Towards a Reflexive Sociology (Stanford: Stanford University Press, 1990); Pierre Bourdieu, The Logic of Practice (Stanford: Stanford University Press, 1990).
} 
monologues, users are connected not only to the attempted destruction of Indigenous groups via forced assimilation but also to a multi-vocal experience of the continuing (and profoundly damaging) reverberations of Canadian settler colonialism today.

The vIRS has been built carefully by adhering to unsettling and decolonizing research principles, such as those found in the OCAP protocol (ownership, control, access, and possession) formulated by Canada's Assembly of First Nations originally to guide "non-extractive" scientific research on Indigenous people and communities. We have also made use of administrative and engagement procedures defined by relational accountability, whereby the role of the researcher is understood to be not simply to extract knowledge from research subjects but rather to form responsible and ongoing relations with those who possess a grounded expertise in the matters being inquired into. ${ }^{49}$ Accordingly, the Embodying Empathy project is owned, controlled, and led by a Survivor Governing Council, who have overseen all levels of the project from methodology design, to ethics, to the build and design of the vIRS itself. ${ }^{50}$

We understand the impact of the vIRS to constitute a form of everyday prevention in light of Domenic LaCapra's (1999) distinction, borrowed from Freud, between "acting-out" and "workingthrough." According to La Capra, "Acting-out is related to repetition, and even the repetitioncompulsion - the tendency to repeat something compulsively." Those acting out consequently "have a tendency to relive the past, to relive the present as if they were still fully in the past, with no distance from it." ${ }^{51}$ For them, the past intrudes into the present in ways that crucially overdetermine the latter's meanings and significance. Acting-out in this context would involve little more than a simple performance of the past - a reliving and return of a trauma that has formerly been repressed, but in a somewhat attenuated form. To simply act-out a residential school experience in a context such as the vIRS would be to make it available to those immersed in the virtual storyworld in a way that simply reaffirms or leaves intact their preexisting beliefs about residential schools. Such an experience would be neither morally nor politically transformative, and would be of extremely limited educational value. In contrast, a virtual world such Embodying Empathy that is designed to encourage empathic unsettlement - a term LaCapra uses to designate that which "poses a barrier to closure in discourse and places in jeopardy harmonizing or spiritually uplifting accounts of extreme events from which we attempt to derive reassurance or a benefit ${ }^{\prime \prime 2}$ - would open up a space of mourning within which it becomes possible to call the present into question by workingthrough differences and disjunctions made available via one's virtual encounter with the past. LaCapra notes that

Mourning involves a different inflection of performativity: a relation to the past that involves recognizing its difference from the present - simultaneously remembering and taking leave of or actively forgetting it, thereby allowing for a critical judgment and a reinvestment in life, notably social and civic life with its demands, responsibilities, and norms requiring respectful recognition and consideration for others. ${ }^{53}$

By participating in mourning conceived as an act of empathic unsettlement, secondary witnesses embedded in the vIRS are not facilely engaging in "the dubious appropriation of the

\footnotetext{
${ }^{49}$ For discussion of Indigenous and decolonizing methods, see Linda Tuhiwai Smith, Decolonizing Methodologies: Research and Indigenous Peoples, 2nd ed. (London: Zed Books, 2012); Shawn Wilson, "What is an Indigenous Research Methodology?" Canadian Journal of Native Education 25, no. 2 (2001), 175-179; Margaret Kovach, Indigenous Methodologies: Characteristics, Conversations, and Contexts (Toronto: University of Toronto Press, 2010); Brian Schnarch, "Ownership Control, Access, and Possession (OCAP) or Self-Determination Applied to Research: A Critical Analysis of Contemporary First Nations Research and Some Options for First Nations Communities," Journal of Aboriginal Health 1, no. 1 (2004), 80-95.

${ }^{50}$ We address these methodological concerns in other publications: see, for example, Adam Muller, Struan Sinclair and Andrew Woolford, "Digitizing Trauma: Embodying Empathy in a Reconstructed Canadian Indian Residential School," in Wor(l)ds of Trauma: Canadian and German Perspectives, ed. Wolfgang Kloos (Münster and New York: Waxman, 2018).

${ }^{51}$ Dominic LaCapra, Writing History, Writing Trauma (Baltimore: Johns Hopkins University Press, 2001), 142.

${ }^{52}$ Ibid., 41-42.

${ }^{53}$ Ibid., 70 .
} 
status of the victim," or otherwise reliving the past to make it cohere with the present. ${ }^{54}$ Instead, they oscillate between past and present so as both to come closer to the experience of others and to upset or unsettle themselves in/and the here and now. For LaCapra, "It is dubious to identify with the victim to the point of making oneself a surrogate victim who has a right to the victim's voice or subject position. The role of empathy and empathic unsettlement in the attentive secondary witness does not entail this identity; it involves a kind of virtual experience through which one puts oneself in the other's position while recognizing the difference of that position and hence not taking the other's place." ${ }^{55}$ Through Embodying Empathy we have worked to create an experience for users that neither completely disconnects their present from the past nor merely replicates the past in their present. Instead, we have worked to have the vIRS produce emotions and affiliations conducive to empathetic unsettlement, and through the experience of this unsettling an empathetically enriched and cognitively enhanced appreciation of the traumatic experiences of social and moral solidarity and betrayal marking the lives of Indigenous residential schoolchildren.

Empathic unsettlement nudges us toward ethical behavior, since it puts a confrontation with the past in the service of reworking relationships today. It is a sufficiently experientially rich and morally worthwhile goal to pursue, but building it into a virtual storyworld presented all of us working on Embodying Empathy with a host of challenges. Our strategic use of inherently unbounded, multivocal and narratively rich virtual space-time has allowed for the production of serial counter-memories that now co-exist within the vIRS. Because of their (sometimes contradictory) co-presence, these countermemories forestall possible harmonizing narratives marshaled not just by the state but by members of a wide range of advocacy groups in order to promote generically untroubled (and therefore static and unresponsive) forms of reconciliation and redress. The immersive environment we have co-created demands complex forms of engagement with Survivor experiences, as they are expressed in their own words, within a haunted yet immediate and viscerally lifelike space composed from Survivor memories.

The Embodying Empathy storyworld is not an open world in the fashion of some contemporary (especially multi-player) video games. Instead it is an environment in which users are directed along a specific narrative path that leaves directional and other choices up to the user, but that in strategic (though subtle) ways overdetermines their exposure to the storyworld's traumatic content. The everyday terrors of forced assimilation, including aspects of colonial intimacy, are present in every glance. As part of an experiment in virtual embodiment, users are immersed in and in contact with the virtual world through the agency of the 360-degree visual and auditory perspectives provided by an Oculus Rift headset. This level of embodiment is intended to increase users' exposure to colonial intimacies as they confront objects and experiences in the storyworld: the Lacombe's ladder that contrasts the assimilative path to heaven with the Indigenous road to hell; the clerical shadows that haunt the chapel and dormitories; on the ride to the residential school in a van in which the seat is too large and distance from the driver is expressionistically magnified; in the intimate, searching text fragments that appear on a bathroom mirror in the girl's dormitory, covered over with cardboard to guard against vanity, and the pages of a missal on display in the dark, isolated furnace room. These experiences recruit users into a kind of muted trauma that is intended to upset and unsettle - not by subjecting them to immediate pain or distress, but rather by requiring them to rethink their relations with Indigenous others who underwent such violence, as well as with the state that thought it acceptable to use these institutional techniques to forcibly transform (and thereby destroy) entire peoples. The Embodying Empathy vIRS had been created to inspire a change in its users' everyday relationality, and through this alteration contribute to the quotidian practice of genocide prevention.

\section{Initial Findings}

Our purpose in this paper is primarily conceptual; however, it is worth reporting on some of the early but suggestive findings from our lab-based study and public exhibition of the vIRS. In an initial qualitative study, carried out alongside a more ambitious psychological investigation

\footnotetext{
${ }^{54}$ Ibid., 82.

${ }^{55}$ Ibid., 78.
} 
that in the near future will provide quantitative data on the empathy-generating capacity of the vIRS ${ }^{56}$ twenty University students were introduced to the vIRS through a 15-minute tour of its space followed by a one-hour, semi-structured lifeworld interview. The lifeworld interview is not intended to measure a specific phenomenon, or individual reactions to it. Instead, this interview strategy seeks to develop rapport with the research participant in order to examine how this individual makes sense of their experiences. ${ }^{57}$ Research participants ranged in age from 19 to 40, with the majority being in the 19-22 age range. Most (65\%) identified as male, which is unusual for a sample drawn from the pool of first-year Psychology students at the University of Manitoba, who predominantly identify as female. Many suggested they were drawn to participate in the study because they enjoy video games or had a curiosity about virtual reality, and saw their participation as providing an opportunity to try it out. Most of our group were Canadian citizens, though we also interviewed a handful (five) who were either landed immigrants or international students. No one in our sample identified as an Indigenous person.

All participants had learned about Canadian residential schools in either their high school or university classes. All were familiar with Survivor retellings of their experiences, and had either read this testimony in textual form (e.g., memoir) or heard it recounted in documentary films. Even so, every one of our participants felt this testimony was enhanced in some fashion when situated within the virtually reconstructed residential school. While many felt they gained new knowledge of residential schools through their experience of virtual immersion, this was not what they cited as the primary takeaway from their engagement with the vIRS. Instead, they remained most alive to how their feelings of sadness, ${ }^{58}$ unease,${ }^{59}$ anger ${ }^{60}$ loneliness ${ }^{61}$ and other emotions were intensified by the experience of being in the location where the harm occurred. One participant reported: "I definitely felt like I was there" and how the vIRS allowed her to "... take more, give more meaning to it. ...It helps you understand more, in a sense." ${ }^{62}$ Another noted that "it definitely made me feel more like I was a part of what they were actually saying when I was in the actual place they were describing." ${ }^{63}$ Moreover, their sense of intimate connection to the Survivors was heightened since they felt closer to their experiences of isolation, injustice, and abandonment.

When asked what empathy meant to them, most students were able to articulate a sense of the concept, though never in a textbook or clinical manner. They described empathy, in general, as the experience of "being in the shoes of another," 64 "connecting with them," ${ }^{\prime 65}$ "helping someone," ${ }^{66}$ or "to feel what another person is going through." ${ }^{67}$ All but one felt their empathy toward Survivors, however they understood the term, was increased through their experience of the vIRS. They explained that this was the case because of the "eeriness" 68 or the palpable "loneliness" 69 of the vIRS. Their recall of the Survivor testimony they heard was also very good, demonstrating that the

\footnotetext{
${ }^{56}$ Early quantitative results from a partnered study of approximately 160 participants are also promising in terms of the effectiveness of the vIRS. When compared to the no intervention control condition, the vIRS had a positive effect in terms of enhanced empathy, perceptions of ongoing suffering due to residential schools, feelings of political solidarity with Survivors, the number of expressed intentions to act, and low levels of distress. These findings are still under analysis and will be published separately by Katherine Starzyk's social psychology lab research team.

${ }^{57}$ See Steiner Kvale and Svend Brinkman, InterViews: Learning the Craft of Qualitative Research Interviewing (Los Angeles: Sage, 2009).

${ }^{58}$ Participant 5, 10, 11.

${ }^{59}$ Participant 4, 10.

${ }^{60}$ Participant 6.

${ }^{61}$ Participant 17, 20.

${ }^{62}$ Participant 3.

${ }^{63}$ Participant 4.

${ }^{64}$ Participants 1, 2, 4, 10.

${ }^{65}$ Participant 3.

${ }^{66}$ Participant 14.

${ }^{67}$ Participant 6, 11, 18.

${ }^{68}$ Participants 2, 4, 8, 20.

${ }^{69}$ Participant 8.
} 
Survivor experiences had in some sense sunk in and "stuck," at least for the moment. Interestingly, the one participant who did not feel he had experienced empathy also self-identified as an avid video game player. For this person, the experience of the vIRS was less emotionally powerful because he adopted strategies he used when playing tense action or horror video games so as to avoid feeling distress or unwanted surprise. ${ }^{70}$

Aside from this one individual, other participants expressed their sense of connection to Survivors and a desire to communicate their concern to these individuals. Some wanted to know whether or not the Survivors are "okay now."71 Others wanted to "congratulate them" or express respect for their "bravery" or "strength"72 for surviving such a horrifying milieu. Connecting this to their day-to-day lives, these participants felt less able to address the broader national project of "reconciliation" and suggested instead how they hoped to live in a way that respected the cultures and ways of being of Canadian Indigenous peoples: "I will go and do, like, a little research and find out more about them;"73 "I just want to listen to them talking for more about their experience."74

We have also exhibited the vIRS at four local high schools. For ethics reasons, we have not collected data in these settings and can only speak anecdotally to the students' reactions. For the high school pop-up exhibitions, students first listen to members of the Embodying Empathy Survivor Governing Council recount their residential school experiences before visiting the vIRS in groups of two. Some students have noted how seeing the space helps make the Survivors' testimony more vivid, and we have at times heard audible gasps from the young people as they navigate the various spaces comprising the virtual storyworld. However, this is also the one setting where Indigenous students have visited the vIRS, and their reactions have ranged from feeling too close to the experiences depicted and needing to exit the storyworld immediately because of resurfacing trauma, to feeling the vIRS "sugar coats" Survivors' experiences because we are unable to include graphic representations of sexual and physical violence when presenting the storyworld to younger students.

These findings are preliminary but suggest that the affective space of the vIRS is a context in which study participants heightened their emotional connection to residential school Survivors. Participants did not pretend that they had experienced what Survivors had experienced, or that they could somehow act out life in a residential school and in so doing achieve a full understanding of that life. Rather, the data suggests that participants were thoughtfully encouraged by the vIRS to work through many of the harms of residential schooling. Several asked that in future iterations of the storyworld we include more representations of hardship, particularly of the sexual and physical abuse that was a common feature of residential schools. ${ }^{75}$ Altogether study participants gave us reason to continue believing that empathic unsettlement can serve as a means of molecular prevention, the latter deriving from participants' reflection on how they could embody greater respect for and recognition of distinct Indigenous cultures. Through empathic acts of role-taking, emotional connection, and expression of ongoing concern for Survivors, the participants in this study are displaying an initial experience of behavioral change through their engagement with the Embodying Empathy storyworld. ${ }^{76}$ The question remains as to how long this behavioral change lasts after they depart from the storyworld; nonetheless, it suggests the vIRS holds some promise for instilling an everyday ethic of prevention.

\section{Conclusion: Multiplying Prevention}

In recent years, greater emphasis has been placed on the scientific aspects of genocide risk assessment and prevention. The persistence and immediacy of genocide, not to mention the

\footnotetext{
${ }^{70}$ Participant 13.

${ }^{71}$ Participant 14.

${ }^{72}$ Participant 5, 10, 11.

${ }^{73}$ Participant 2

${ }^{74}$ Participant 5.

${ }^{75}$ Participant 11.

${ }^{76}$ For further discussion of empathy and behavioral change, see Benjamin M.P. Cuff, et al, "Empathy: A Review of the Concept," Emotion Review 8, no. 2 (April 2016), 144-153.
} 
devastating experience of witnessing the suffering it entails, has the obvious consequence of driving us toward similarly immediate responses. In the face of such suffering, critique as an explanatory and moral-political project can seem untimely, irrelevant, or inappropriate. It is not for lack of solidarity with suffering others that we engage here in the critique of prevention. We follow Wendy Brown and view critique as resisting the closing-in of the present upon us, rejecting its inevability, and providing us with the means to imagine it differently. ${ }^{77}$ More precisely, critiquing how the prevention concept is used in a specific time and place is not an act of indifference; it is a sincere effort to broaden our horizons of understanding, and with them the possibilities of justice and redress. As a complex problem, or maybe better as a complex of problems, prevention should not be rushed into, pragmatically, conceptually, or otherwise.

In our view, the rush to prevention speaks for a deeper (and in many ways understandable) desire for immediate action as well as a realpolitik that wages the battle against genocide at a molar level. Prior to critique of the sort we aim to offer here, prevention makes itself available to recognize and address only certain types of genocide identifiable through surface acts of recognition. A truly critical approach to genocide prevention needs to look to multiplying prevention through the proliferation of everyday resistance to genocidal practices and logics. Embodying Empathy, which may be more familiarly conceived of as a project revolving around concerns with genocide representation, can, we believe, also operate to initiate and sustain everyday forms of genocide prevention, designed to counter habits and practices conducive to the destruction of group life. In particular, it potentially awakens users to the cultural destruction wrought through the genocidal intimacies of the residential school, providing an embodied experience directed toward shifting users' future beliefs and practices away from the ongoing destructiveness of Canadian settler colonialism.

\section{Acknowledgements}

The Research presented in this paper was undertaken with approval from the University of Manitoba Psychology/Sociology Research Ethics Board. Funding for our project was provided by a Social Sciences and Humanities Council of Canada Partnership Development Grant. We would like to acknowledge Theodore Fontaine, Caroline Perreault, Mary Courchene, David Rundle Sr., Daniel Highway, Purvis Fontaine, and William Morriseau, whose expertise made this research possible. We also thank Wanda Hounslow, Prairie Skye Young-Brown, Toni Kipling, and Allysa Bird for their research assistance. Further thanks to participants in the Critical Approaches to Genocide and Atrocity Prevention Workshop for their helpful feedback and stimulating discussion.

\section{Bibliography}

Abtahi, Hirad and Philippa Webb. The Genocide Convention: The Travaux Préparatoires, 1st ed. Leiden and Boston: Martinus Nijhoff, 2008. Doi: 10.1163/ej.9789004164185.i-2236

Albright, Madeline K. and William S. Cohen. Preventing Genocide: A Blueprint for U.S. Policymakers. Washington, DC: United States Holocaust Memorial Museum, 2008. Accessed January 14, 2019. https://www.ushmm.org/m/pdfs/20081124-genocide-prevention-report. pdf.

Anderson, Kjell. "Colonialism and Cold Genocide: The Case of West Papua." Genocide Studies and Prevention 9, no. 2, (2015), 9-25. Doi: 10.5038/1911-9933.9.2.1270

Bauman, Zygmunt. Modernity and the Holocaust. Ithaca: Cornell University Press, 2000.

Beck, Ulrich. "From Industrial Society to the Risk Society: Questions of Survival, Social Structure and Ecological Enlightenment." Theory, Culture \& Society 9, no. 1 (1992), 97-123. Doi: 10.1177/026327692009001006

Benvenuto, Jeffrey. "From Cultural Genocide to Cultural Integrity: Indigenous Rights and the Cooptation of International norms." Unpublished PhD diss., Rutgers University, 2018.

Bloom, Paul. Against Empathy: The Case for Rational Compassion. New York: HarperCollins/Ecco, 2016. Doi: 10.1007/s12115-018-0236-Z

\footnotetext{
${ }_{77}$ Wendy Brown, Edgework: Critical Essays on Knowledge and Politics (Princeton: Princeton University Press, 2005).
} 
Bourdieu, Pierre. In Other Words: Essays Towards a Reflexive Sociology. Palo Alto: Stanford University Press, 1990.

---------. The Logic of Practice. Ithaca: Stanford University Press, 1990.

Brehm, Nyseth H. "Re-examining Risk Factors of Genocide." Journal of Genocide Research 19, no. 1 (2017), 61-87. Doi: 10.1080/14623528.2016.1213485

Brown, Wendy. Edgework: Critical Essays on Knowledge and Politics. Princeton: Princeton University Press, 2009.

Clastres, Paul. “On Ethnocide." Art \& Text 28 (1988), 51-58

Cahill, Cathleen D. Federal Mothers and Fathers: A Social History of the United States Indian Service, 1869-1933. Chapel Hill: University of North Carolina Press, 2011.

Card, Claudia. Confronting Evils: Terrorism, Torture, Genocide. Cambridge: Cambridge University Press, 2010.

Charney, Israel W. and Roger W. Smith. “Why GSP?" Genocide Studies and Prevention 1, no. 2 (2006), i-ii.

Clarke, John N. “Early Warning Analysis for Humanitarian Preparedness and Conflict Prevention." Civil Wars 7, no. 1 (2005), 71-97. Doi: 10.1080/13698280500074446

Clifford, James. The Predicament of Culture: Twentieth-Century Ethnography, Literature, and Art. Cambridge: Harvard University Press, 1988. Doi: 10.2307/j.ctvif9x0h

Conley, Tom. "Molar." In The Deleuze Dictionary, edited by Adrian Parre, 171-172. Edinburgh: Edinburgh University Press, 2005.

Cuff, Benjamin M.P., Sarah J. Brown, Laura Taylor, and Douglas J. Howat. "Empathy: A Review of the Concept." Emotion Review 8, no. 2 (April 2016), 144-153. Doi: 10.1177/1754073914558466

Deleuze, Gilles and Félix Guattari. A Thousand Plateaus: Capitalism and Schizophrenia. London: Bloomsbury Publishing, 1988.

Ericson, Richard Victor and Aaron Doyle. Uncertain Business: Risk, Insurance and the Limits of Knowledge. Toronto: University of Toronto Press, 2004. Doi: 10.3138/9781442682849

Goldsmith, Benjamin E., Charles R. Butcher, Dimitri Semenovich, and Arcot Sowmya. "Forecasting the Onset of Genocide and Politicide: Annual Out-of-Sample Forecasts on a Global Dataset, 1988-2003." Journal of Peace Research 50, no. 4 (2013), 437-452. Doi: 10.1177/0022343313484167

Goldsmith, Benjamin E. and Charles Butcher. "Genocide Forecasting: Past Accuracy and New Forecasts to 2020." Journal of Genocide Research 20, no. 1 (2018), 90-107. Doi: 10.1080/14623528.2017.1379631

Grant, Agnes. No End of Grief: Residential Schools in Canada. Winnipeg: Pemmican Publications, 1996.

Haken, Nate, J. J. Messner, Krista Hendry, Patricia Taft, Kendall Lawrence, Laura Brisard, and Felipe Umana. Fragile States Index 2014. Washington, DC: The Fund for Peace. 2014.

Hacking, Ian. The Taming of Chance. Cambridge: Cambridge University Press, 1990.

Hamburg, David A. Preventing Genocide: Practical Steps Toward Early Detection and Effective Action. New York: Routledge, 2015. Doi: 10.4324/9781315632599

Harff, Barbara. "Detection: The History and Politics of Early Warning." In Responding to Genocide: The Politics of International Action, edited by Adam Lupel and Ernesto Verdeja, 85-110. Boulder: Lynne Rienner Publishers, Inc., 2013.

. "No Lessons Learned from the Holocaust? Assessing Risks of Genocide and Political Mass Murder since 1955." American Political Science Review 97, no. 1, (2003), 57-73. Doi: 10.1017/ $\underline{\mathrm{s} 0003055403000522}$

Hazlett, Chad. New Lessons Learned? Improving Genocide and Politicide Forecasting. Washington, DC: United States Holocaust Memorial Museum, 2011. Accessed January 7, 2019. https://www. ushmm.org/m/pdfs/20111102-hazlett-early- warning-lessons-learned.pdf.

Heldt, Birger. "Risks, Early Warning and Management of Atrocities and Genocide: Lessons from Statistical Research." Politorbis 47, no. 2 (2009), 65-70.

Hinton, Alexander Laban. "Critical Genocide Studies." Genocide Studies and Prevention 7, no. 1 (2012), 4-15.

. Why Did they Kill? Cambodia in the Shadow of Genocide. Berkeley: University of California Press, 2005. 
Irvin-Erickson, Douglas. Raphaël Lemkin and the Concept of Genocide. Philadelphia: University of Pennsylvania Press.

Jacobs, Margaret D. White Mother to a Dark Race: Settler Colonialism, Maternalism, and the Removal of Indigenous Children in the American West and Australia, 1880-1940. Lincoln: University of Nebraska Press, 2009.

. "The Habit of Elimination: Indigenous Child Removal in Settler Colonial Nations in the Twentieth Century." In Colonial Genocide in Indigenous North America, edited by Andrew Woolford, Jeff Benvenuto, and Alexander Laban Hinton, 189-207. Durham: Duke University Press, 2014.

Kossak, Mitchell. Attunement in Expressive Art Therapy: Toward an Understanding of Embodied Empathy. Springfield: Charles C. Thomas, 2015.

Kovach, Margaret. Indigenous Methodologies: Characteristics, Conversations, and Contexts. Toronto: University of Toronto Press, 2010.

Kuper, Leo. Genocide: Its Political Use in the Twentieth Century. New Haven: Yale University Press, 1981.

Kvale, Steiner and Svend Brinkman. InterViews: Learning the Craft of Qualitative Research Interviewing. Los Angeles: Sage, 2009.

LaCapra, Dominick. Writing History, Writing Trauma. Baltimore: Johns Hopkins University Press, 2001.

Lemkin, Raphael. Totally Unofficial: The Autobiography of Raphael Lemkin. New Haven: Yale University Press, 2013.

Lord, Albert B. The Singer of Tales. New York: Atheneum, [1960] 1965.

MacDonald, David B. and Graham Hudson. "The Genocide Question and Indian Residential Schools in Canada." Canadian Journal of Political Science 45, no. 2 (2012), 427-449. Doi: 10.1017/s000842391200039x

Macgregor, Russell. "Governance, Not Genocide: Aboriginal Assimilation in the Postwar Era." In Genocide and Settler Society: Frontier Violence and Stolen Indigenous Children in Australian History, edited by A. Dirk Moses, 290-311. New York: Berghahn Books, 2004.

Matveeva, Anna. Early Warning and Early Response: Conceptual and Empirical Dilemmas. The Hague: European Centre for Conflict Prevention/International Secretariat of the Global Partnership for the Prevention of Armed Conflict, 2006.

Meyer, Christoph O., Florian Otto, John Brante, and Chiara De Franco. "Recasting the WarningResponse Problem: Persuasion and Preventive Policy." International Studies Review 12, no. 4 (2010), 556-578. Doi: 10.1111/j.1468-2486.2010.00960.x

Miller, James Rodger. Shingwauk's Vision: A History of Native Residential Schools. Toronto: University of Toronto Press, 1996.

Miller, Peter and Nikolas Rose. "Governing Economic Life." Economy and Society 19, no. 1 (1990), $1-31$.

Milloy, John S. A National Crime: The Canadian Government and the Residential School System, 1879 to 1986. Winnipeg: University of Manitoba Press, 1999.

Morsink, Johannes. "Cultural Genocide, the Universal Declaration, and Minority Rights." Human Rights Quarterly 21, no. 4 (1999), 1009-1060. Doi: 10.1353/hrq.1999.0052

Moses, A. Dirk. "Conceptual Blockages and Definitional Dilemmas in the 'Racial Century': Genocides of Indigenous Peoples and the Holocaust." Patterns of Prejudice 36, no. 4 (2002), 7-36. Doi: 10.1080/003132202128811538

Muller, Adam. Concepts of Culture: Art, Politics, and Society. Calgary: University of Calgary Press, 2005.

Muller, Adam, Struan Sinclair, and Andrew Woolford. “Digitizing Trauma: Embodying Empathy in a Reconstructed Canadian Indian Residential School." In Wor $(l) d s$ of Trauma: Canadian and German Perspectives, edited by Wolfgang Kloos, 249-263. Münster and New York: Waxman, 2018.

Powell, Christopher. Barbaric Civilization: A Critical Sociology of Genocide. Montreal and Kingston: McGill-Queen's University Press, 2011. 
Rost, Nicolas. "Will it Happen Again? On the Possibility of Forecasting the Risk of Genocide." Journal of Genocide Research 15, no. 1 (2013), 41-67. Doi: 10.1080/14623528.2012.759398

Schnarch, Brian. "Ownership Control, Access, and Possession (OCAP) or Self-Determination Applied to Research: A Critical Analysis of Contemporary First Nations Research and Some Options for First Nations Communities." International Journal of Indigenous Health 1 , no. 1 (2004), 80-95.

Smith, Linda Tuhiwai. Decolonizing Methodologies: Research and Indigenous Peoples, 2nd ed. London: Zed Books, 2012.

Stanton, Gregory H. "How we can Prevent Genocide: Building an International Campaign to End Genocide." Genocide Watch, 2003. Accessed January 14, 2019. http://www.genocidewatch. org/howpreventgenocideic.html.

--------. "The Ten Stages of Genocide." Genocide Watch, 2016. Accessed December 5, 2018. http:// www.genocidewatch.net/wp-content/uploads/2012/06/The-Ten-Stages-of-Genocidehandout.pdf.

Stoler, Laura Ann. Carnal Knowledge and Imperial Power: Race and the Intimate in Colonial Rule. Berkeley and Los Angeles: University of California Press, 2002.

Straus, Scott. Fundamentals of Genocide and Mass Atrocity Prevention. Washington, DC: United States Holocaust Memorial Museum, 2016. Accessed January 14, 2019. https://www.ushmm. $\mathrm{org} / \mathrm{m} / \mathrm{pdfs} /$ Fundamentals-of-Genocide-and-Mass-Atrocity-Prevention.pdf.

Truth and Reconciliation Commission of Canada. Honouring the Truth, Reconciling for the Future. Summary of the Final Report of the Truth and Reconciliation of Canada. Ottawa: Government of Canada, 2015.

United Nations. General Assembly Resolution 260, Convention on the Prevention a Punishment of the Crime of Genocide. December 9, 1948. UN Doc. A/RES/260(III).

United Nations Office of the Special Adviser for the Prevention of Genocide and the Responsibility to Protect. Framework of Analysis for Atrocity Crimes: A Tool for Prevention. New York: United Nations, 2014.

van Krieken, Robert. "Rethinking Cultural Genocide: Aboriginal Child Removal and SettlerColonial State Formation." Oceania 75 (2004), 125-151. Doi: 10.1002/j.1834-4461.2004. tb02873.x

Vansina, Jan. Oral Tradition as History. Madison: University of Wisconsin Press, 1985.

Weiss-Wendt, Anton. The Soviet Union and the Gutting of the UN Genocide Convention. Madison: University of Wisconsin Press, 2017.

Wilson, Shawn. "What is an Indigenous Research Methodology?" Canadian Journal of Native Education 25, no. 2 (2001), 175-179.

Wolfe, Patrick. "Settler Colonialism and the Elimination of the Native." Journal of Genocide Research 8, no. 4 (2006), 387-409. Doi: 10.1080/14623520601056240

Woolford, Andrew. "Ontological Destruction: Genocide and Aboriginal Peoples in Canada." Genocide Studies and Prevention 4, no. 1 (2009), 81-97. Doi: 10.1353/gsp.0.0010

-------. This Benevolent Experiment: Indigenous Boarding Schools, Genocide and Redress in North America. Lincoln and Winnipeg: University of Nebraska and the University of Manitoba Press, 2015.

. "Decriminalizing Settler Colonialism: Entryways to Genocide Accusation and Canadian Absolution." In Entryways and Criminalization, edited by George Pavlich and Matthew Unger, 139-164. Edmonton: University of Alberta Press, 2019. 